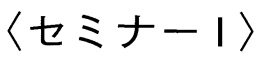

\title{
長崎県における肺癌の疫学と肺癌検診
}

\author{
早田 宏 1,2 ・富田弘志 1 ・早田みどり 3 ・ \\ 岡三喜男 $2 \cdot$ 河野 茂 2
}

要旨一一目的. 長崎県における胸部 X 線と喀痰細胞診を用いた肺癌住民検診の効果について, 会議録として予備報告 を行う. 方法. 地域がん登録のデータを用い，検診の効果を評価した．結果. 検診の効果は組織型や性別で異なって いた．結論．肺癌検診の効果を評価する場合には，肺癌の多様性を考慮すべきである（肺癌．2002;42:829-831）

索引用語 一一肺癌, 疫学, 検診, 発見率

\section{Meeting Report: Epidemiology and Screening for Lung Cancer in Nagasaki, Japan}

\author{
Hiroshi Soda ${ }^{1,2}$; Hiroshi Tomita ${ }^{1}$; Midori Soda ${ }^{3}$; \\ Mikio Oka ${ }^{2}$; Shigeru Kohno ${ }^{2}$
}

\begin{abstract}
Objectives. We made a preliminary report regarding the effectiveness of population-based screening with chest radiography and sputum cytology for lung cancer in Nagasaki Prefecture, Japan. Methods. Using data of the population-based cancer registry, the effectiveness of screening was evaluated. Results. The effectiveness of screening varied according to histological type and gender. Conclusions. The heterogeneity of lung cancer should be considered when evaluating the effectiveness of screening for lung cancer. (JJLC. 2002;42:829-831)
\end{abstract}

KEY WORDS — Lung cancer, Epidemiology, Screening, Detection rate

\section{緒 言}

肺癌検診の有効性については, ランダム化比較試験で 死亡率を減少させることが証明できなかったため, 1,2 欧 米では健康施策として推奨されていない。一方，近年わ が国で行われた症例対照研究からは現行の肺癌検診の有 効性を示唆する結果も得られているが, 3,4 新たな胸部 CT 検診の導入を求める考えもある.5-8 肺癌の多くは腺 癌, 扁平上皮癌, 大細胞癌, 小細胞癌の組織型に分類さ れ, 我々は検診および禁煙の効果が組織型別に異なる可 能性を報告してきた. ${ }^{9-11}$ 今回, 地域がん登録から肺癌検
診を組織型別に再検討し，将来の肺癌対策に向けた問題 点を明らかする。

方 法

\section{（1）長崎県の肺癌の疫学}

1986 年から 1995 年の 10 年間に長崎県がん登録に新 規登録された原発性肺癌症例を解析した。

（2）長崎県における胸部住民検診

1997 年から 2000 年度の 4 年間に長崎県内の 6 市, 60〜 66 町， 1 村より委託を受けて胸部住民検診を行った。検 診方法は，間接撮影の二重読影・比較読影と喫煙指数
1 長崎県総合保健センター ; 2 長崎大学医学部第二内科 ; 3 長 崎県がん登録室, 放射線影響研究所.

別刷請求先：早田 宏, 長崎大学医学部第二内科, $\bar{\top} 852-8501$ 長崎市坂本 1 丁目 7 番 1 号 (e-mail: soda@net.nagasaki-u.ac.jp).

${ }^{1}$ Nagasaki Prefectural Medical Health Center, Japan; ${ }^{2}$ Second Department of Internal Medicine, Nagasaki University School of Medicine, Japan; ${ }^{3}$ Nagasaki Prefectural Cancer Registry, Radia- tion Effects Research Foundation, Japan.

Reprints: Hiroshi Soda, Second Department of Internal Medicine, Nagasaki University School of Medicine, 1-7-1 Sakamoto, Nagasaki-shi, 852-8501 Nagasaki, Japan(e-mail: soda @ net. nagasaki-u.ac.jp).

(C) 2002 The Japan Lung Cancer Society 
600 以上の対象者に対して喀痰細胞診を併用した.

なお, 今回の研究は長崎大学医学部倫理委員会の承認 を得て解析を行った。

\section{結 果}

（1）長崎県の肺癌の疫学

10 年間で男性肺癌 5,668 人, 女性肺癌 2,309 人が長崎 県 (1990 年国勢人口 ; 男性 736,729 人, 女性 826,230 人) で登録された。年齢調整罹患率（基準人口：0〜100 歳の 昭和 60 年日本モデル人口）は，男性 10 万対 65.8 , 女性 10 万対 18.3 であった。

組織型判明率は 0 79 歳で 78\%，80 歳以上で $42 \%$ で あった．肺癌の組織型の内訳をみると，男性は腺癌 40.7 $\%$, 扁平上皮癌 $36.7 \%$ と腺癌がやや多く, 女性では, 腺 癌 $72.2 \%$, 扁平上皮癌 $13.7 \%$ と多くが腺癌であった.

年齢・組織型別に罹患率をみると, 男性では腺癌が中 年層にやや多かったが, 女性では腺癌は明らかに中年層 に多かった。

79 歳以下の非小細胞肺癌の進展度は限局型が $26 \%$, 局 所進展型が $30 \%$, 遠隔転移型が $27 \%$, 不明が $17 \%$ で, 5 年生存率は男性 $22 \%$ ，女性 $30 \%$ であった。組織型別に みると, 5 年生存率は男性腺癌 $22 \%$, 男性扁平上皮癌 22 $\%$, 女性腺癌 34\%, 女性扁平上皮癌 $17 \%$ であり, 女性腺 癌の予後が最も良好であった。

\section{（2）長崎県における胸部住民検診}

4 年間（1997〜2000 年）の延べ受診者数は，412,314 人（男性 150,980 人，女性 261,334 人）であり，その中で 喀痰細胞診の受診者は 18,025 人であった．受診者数の ピークは，男女とも 65〜69 歳に認められた.

2000 年度の受診者を喫煙指数別にみると, 男性 34,673 人中，契煙なしが $44.2 \%$ ，契煙指数 600 以下が $23.3 \%$ ， 指数 601 以上が $32.5 \%$ で，女性 59,216 人中，喫煙なしが $97.0 \%$, 指数 600 以下が $2.4 \%$, 指数 601 以上は $0.6 \%$ で あった。女性ではほとんどが非契煙者であった。

4 年間の発見肺癌は 328 人 (男性 217 人, 女性 111 人) であった. 粗発見率は男性 10 万対 143.7 ，女性 42.5 であ り, 年齢調整発見率 (基準人口：0〜100 歳の昭和 60 年日 本モデル人口) は, 男性 10 万対 43.9 ，女性 13.7 であった. 発見方法は，胸部 X 線のみの発見が 298 人，喀痰細胞診 のみの発見が 8 人, 両方によるものが 22 人であった.

組織型別の内訳では, 男性肺癌 217 人中, 腺癌 97 人 $(44.7 \%)$, 扁平上皮癌 77 人 $(35.5 \%)$ と腺癌の発見数が やや多かった。一方, 女性肺癌では 111 人中腺癌は 88 人 $(79.3 \%)$ で, 扁平上皮癌の発見はなく, 腺癌が多くを 占めていた。さらに喫煙別に見ると, 男性腺癌で喫煙者 は $77.3 \%$, 男性扁平上皮癌で $85.5 \%$, 女性腺癌で $4.5 \%$ で あり，女性腺癌のほとんどが非喫煙者であった。

腫瘍径別にみると, 腺癌は径 $1.0 \mathrm{~cm}$ 以下が $10.6 \%$,
$1.1 \sim 2.0 \mathrm{~cm}$ が $41.2 \%, 2.1 \sim 3.0 \mathrm{~cm}$ が $20.6 \%, 3.1 \mathrm{~cm}$ 以上 が $27.6 \%$ であった。一方, 扁平上皮癌は径 $1.0 \mathrm{~cm}$ 以下が $11.1 \% ， 1.1 \sim 2.0 \mathrm{~cm}$ が $20.6 \% ， 2.1 \sim 3.0 \mathrm{~cm}$ が $25.4 \%$, $3.1 \mathrm{~cm}$ 以上が $42.9 \%$ であった. 腺癌の約半数が径 $2.0 \mathrm{~cm}$ 以下で発見されていたが, 扁平上皮癌は径 $3.1 \mathrm{~cm}$ 以上も 少なくなかった。

病期の内訳は，発見肺癌 328 人中 $0-\mathrm{I}$ 期 154 人 $(47.0$ \%)で, 病期の判明した症例でみると 0-I 期の占める割合 は $52.7 \%$ であった。

検診の効率を長崎県での性・年齢別罹患率による標準 化発見比（発見数/期待值）でみると，全体で 0.63 (男性 0.59，女性 0.73）であった．組織型別では腺癌 1.03 (男性 0.93, 女性 1.16), 扁平上皮癌 0.63 であった.

\section{考 察}

地域がん登録は，わが国の肺癌の全体像を明らかにす るために重要な情報である. 今回の検討では, 病期 I 期に 相当する限局型が $26 \%$ しかなく, 依然として進行した肺 癌が多くを占めていた。また，5年生存率は女性腺癌が $34 \%$ と他の組織型よりも高いものの全体としては不良 であり，今後の肺癌対策は国民の重要な課題である.

今回の住民検診の結果は, 過去に行った検診導入期の 肺癌検診の解析結果とほぼ同様であった. 9 精度管理の 高い検診の維持に努めているにもかかわらず，検診発見 肺癌の病理病期を含めた I 期の割合は $50 \%$ 前後と毎年 ほぼ不変であった. 現行の肺癌検診において，I期肺癌の 割合を $50 \%$ にすることが目標とされているが, 12 この 值を維持するのは難しく，現行の肺癌検診の限界である と考えられる．また，女性の検診受診者および発見肺癌 症例のほとんどが非契煙者であったことは，禁煙活動だ けで肺癌発生の問題が解決しないことを示している.

我々はこれまで腺癌と扁平上皮癌の組織型の差で肺癌 $\mathrm{X}$ 線検診の効果が異なることを報告してきた.9-11 これ までの研究で, 腺癌は X 線検診の感度 $85 \%$ と良好では あるものの, 倍加時間の中央值が 174 日と長く, lead time も極めて長いことが算出された. 9,10 一方, 扁平上皮癌は 倍加時間が 70 日と発育が速く, X 線検診の感度も $52 \%$ と不良であった.9,10 また, 長崎県での性・年齢別の肺癌 䍜患率の変動より, 男性では扁平上皮癌のみならず腺癌 も喫煙の影響を受けている可能性があることを報告して きた.11 今回，がん登録を利用した標準化発見比により 検診の効果を推定したところ，女性が男性よりも発見効 率が高かった。 また, 組織型別の標準化発見比は組織型 不明例の影響を受けて高めにでる可能性があるものの, 扁平上皮癌よりも腺癌, 男性腺癌よりも女性腺癌の発見 効率が高かった。

このように, 肺癌は, 組織型, 性別, 喫煙状況によっ て生物学特性が異なる可能性があり，禁煙や検診の効果 
も一様ではないと推測される. 現在, 胸部 CT 検診の普及 で小型の細気管支肺胞上皮癌を発見する機会が増えてい る. 5-7 今後, 胸部 CT 検診の効果を評価する場合には, 肺 癌の多様性を考慮して検討すべきと考えられる。また， 発育が速い扁平上皮癌の発生の対策として，積極的な禁 煙活動をあわせて行うべきである。

\section{REFERENCES}

1. Fontana RS, Sanderson DR, Woolner LB, et al. Lung cancer screening. The Mayo Program. J Occup Med. 1986;28: 746-750.

2. Fontana RS, Sanderson DR, Woolner LB, et al. Screening for lung cancer: A critique of the Mayo Lung Project. Cancer. 1991;67:1155-1164.

3. Sagawa M, Tsubono Y, Saito M, et al. A case-control study for evaluating the efficacy of mass screening program for lung cancer in Miyagi Prefecture, Japan. Cancer. 2001;92:588-594.

4. Tsukada H, Kurita Y, Yokoyama A, et al. An evaluation of screening for lung cancer in Niigata Prefecture, Japan: A population-based case-control study. Br J Cancer. 2001; 85:1326-1331.

5. Sone S, Li F, Yang Z-G, et al. Results of three-year mass screening programme for lung cancer using mobile lowdose spiral computed tomography scanner. $\mathrm{Br} J$ Cancer. 2001;84:25-32.

6. Sobue T, Moriyama N, Kaneko M, et al. Screening for lung cancer with low-dose helical computed tomography: anti-lung cancer association project. J Clin Oncol. 2002; 20:911-920.

7. Nawa $T$, Nakagawa $T$, Kusano $S$, et al. Lung cancer screening using low-dose spiral CT: Results of baseline and 1-year follow-up studies. Chest. 2002;122:15-20.

8. Henschke CI, Naidich DP, Yankelevitz DF, et al. Early Lung Cancer Action Project: Initial findings on repeat screening. Cancer. 2001;92:153-159.

9. Soda H, Tomita H, Kohno S, et al. Limitation of annual screening chest radiography for the diagnosis of lung cancer: A retrospective study. Cancer. 1993;72:2341-2346.

10. Soda H, Oka M, Tomita H, et al. Length and lead time biases in radiologic screening for lung cancer. Respiration. 1999;66:511-517.

11. Soda H, Oka M, Soda M, et al. Birth cohort effects on incidence of lung cancers: A population-based study in $\mathrm{Na}-$ gasaki, Japan. Jpn J Cancer Res. 2000;91:960-965.

12. 日本肺癌学会集団検診委員会. 肺癌集団検診の手引き.日 本肺癌学会, 編集. 肺癌取扱い規約. 改訂第 5 版. 東京： 金原出版 ; 1999. 